\title{
Polylactic Acid as Biodegradable Plastic Material Based on Tofu Dregs
}

\author{
Mohammad Manarul Lubab*, Zahratul Aflah Fatharani Rahimah Sudianto, Permata Maratussolihah, Mustika \\ Nuramalia Handayani \\ Faculty of Technology and Vocational Education \\ Universitas Pendidikan Indonesia \\ Bandung, Indonesia \\ *lubabmanaru197@upi.edu, aflah1308@upi.edu,Permata19@upi.edu, mustika@upi.edu
}

\begin{abstract}
Polylactic acid (PLA) is an environmentally friendly plastic raw material. However, the synthetic lactic acid raw materials needed are relatively expensive. There is an alternative solution to produce lactic acid from other natural resources that are abundant and untapped, such as tofu industrial solid waste, namely tofu dregs. This study aims to explain the potential of tofu dregs as a raw material for Polylactic Acid. The data collection method used was literature review. It is known that Lactobacillus plantarum can hydrolyze the carbohydrate content in tofu dregs into lactic acid. Furthermore, lactic acid is polymerized into Polylactic acid by using the RingOpening Polymerization method to produce Polylactic acid. The carbohydrate content of tofu dregs is potential to be processed into Polylactic acid.
\end{abstract}

Keywords-lactobacillus plantarum, polylactic acid, ringopening polymerization, tofu dregs

\section{INTRODUCTION}

Daily use of plastic is inevitable. The plastic currently used is a synthetic polymer made of fossil (non-renewable) raw materials that cannot be degraded by natural microorganisms [1]. The continuing use of synthetic plastic will generate environmental problems.

The plastic alternatives developed to cope with this problem are using biodegradable plastics. One of the biodegradable plastic types that have improved commercially is PLA (polylactic acid). PLA is made from lactic acid and very environmentally friendly, it can be biodegradable in 2-6 weeks, and also does not produce poison. Lactic acid for PLA can be obtained in natural ingredients that contain starch such as cassava, sweet potato, corn, and wheat [2]. Cargill-Dow Chemical's Co is one of the big company whose produces PLA using corn starch as raw material. Meanwhile, in Japan, Shimadzu Co, and Mitsui Chemicals Co also have a plan to manufacture PLA.

The use of naturally carbohydrate materials mainly from sweet potato, corn, and tapioca as raw materials in biodegradable plastics has become deficient. These materials are basic foodstuffs. The use of these materials in large quantities can disrupt Indonesia's food security. Another problem is most PLA made from synthetic lactic acid and make it expensive.

According to the problem outlined, there is an alternative solution to produce lactic acid from other natural resources that are abundant and untapped, such as tofu industrial solid waste, namely tofu dregs. Carbohydrate content in tofu dregs can be fermented by Lactic Acid Bacteria (LAB) into lactic acid. Furthermore, the resulting lactic acid can be polymerized into PLA by Ring-opening Polymerization (ROP) method. Tofu dregs as a base to produce lactic acid can solve the problem of plastic waste.

According to Direktorat Gizi Depkes Indonesia from reference [3] dried tofu waste contains $26.6 \%$ protein, $18.3 \%$ fat and $41.3 \%$ carbohydrate in 100 grams of material. It means that the tofu waste has many advantages such as containing high protein, lots of fiber, as well as cheap and easy to obtain. It has the potential to be processed into nutritious food products that are beneficial to the human body. This study aims to explain the potential of tofu dregs as a raw material for Polylactic Acid

\section{Methodology}

This study was prepared by literature study based on the PRISMA (Preferred Reporting Items for Systematic Reviews and Meta-Analysis) method. This method is commonly used in literature review research [4]. Literature studies using PRISMA play an important role in solving problems by explaining, synthesizing, and assessing quantitative or qualitative evidence as reports [4].

Literature search was carried out using the keywords "Poly Lactic Acid (PLA)", "Tofu dregs", "Ring Opening Polymerization (ROP)", and "Lactobacillus plantarum" through science webs such as Google Scholar, National Library, Doaj, Science Direct, Elsevier and springerlink. Based on the search strategy used, 25 libraries were retrieved and stored. Then, the same library is deleted. A total of 5 libraries are deleted until the remaining 20 libraries are used. 
The findings obtained from the journal will be reviewed based on the focus of the research, the scope of the problem under study and the results of the research. Then analyzed and extracted important information in it to answer the research objectives in order to answer the research objectives in the literature [5].

\section{RESULTS AND DISCUSSION}

\section{A. Polylactic Acid}

Poly lactic acid (PLA) is an environmentally friendly biodegradable plastic that can be recycled using heat with excellent processing capability, requiring less energy in production compared to petroleum-based polymers [6]. In addition, PLA is also included in renewable plastics that can be converted into packaging [7]. According to Gandini \& Balgacem in reference [8], renewable sources are any plant or animal species that are utilized without endangering their survival and are renewed biologically (short term) not geochemical processes (very long term).

\section{B. Ring-Opening Polymerization}

PLA comes from lactic acid as a result of chemical processes [9]. According to reference [8], PLA synthesis consists of several steps, starting from the production of lactic acid to the polymerization stage. Poly lactic acid can be produced through Ring Opening Polymerization (ROP), which is carried out in three stages, namely lactic acid polycondensation, depolymerization to form cyclic dimers (lactide) and followed by ring opening polymerization, to obtain PLA with high molecular weight. This ROP method was patented by Cargill (United States) in 1992.

The raw materials for obtaining lactate acid can come from ingredients which contain carbohydrates such as potatoes, sweet potato rice, cassava, wheat and corn. However, in fact, carbohydrate sources can also be obtained from untapped and abundant waste without disturbing food security such as tofu dregs.

\section{Tofu Dregs}

Tofu dregs are solid waste from the tofu processing. Tofu dregs are generally used as animal feed or reprocessed as food ingredients such as tempeh gembus [10]. On the other hand, Tofu dregs is solid waste from squeezed soybean porridge and is unused again and have perishable characteristics and lead it to low economic value. Reference [11] also states that tofu dregs has a high enough protein content, however, this feed ingredient contains low dry ingredients or contains a lot of water. The high protein and water content causes the tofu dregs not to last long because it is prone to decay due to the growth of destructive microorganisms. Due to its perishable nature, usually the use of tofu dregs is not more than one day and the farmer is given it on that day. Tofu dregs have enough potential to be reprocessed because they still contain good nutrition [12].
TABLE I. TOFU DREGS CONTENT [3]

\begin{tabular}{|c|c|}
\hline Composition & Quantity (in 100 g dry weight) \\
\hline Protein & $26.6 \%$ \\
\hline Fat & $18.3 \%$ \\
\hline Carbohydrate & $41.3 \%$ \\
\hline
\end{tabular}

TABLE II. TOFu DREGS Flour CONTENT [13]

\begin{tabular}{|c|c|}
\hline Composition & Quantity \\
\hline Water & $10.43 \%$ \\
\hline Protein & $23.25 \%$ \\
\hline Fat & $5.87 \%$ \\
\hline Carbohydrates & $26.92 \%$ \\
\hline Ash & $17.03 \%$ \\
\hline Crude Fiber & $16.53 \%$ \\
\hline
\end{tabular}

Table 1 and 2 show data on the composition of tofu dregs and after processing it into flour tofu dregs, the carbohydrate content of tofu dregs is the highest amount The carbohydrates in the tofu waste can be converted into lactic acid with the help of lactic acid bacteria (LAB). Research by reference [14] states that Lactobacillus plantarum which is $\mathrm{LAB}$ can ferment all types of carbohydrates except melibiose, raffinose, and xylitol.

\section{Lactobacillus Plantarum}

Lactobacillus plantarum is a type of homofermentative lactic acid bacteria with an optimal temperature lower than $37^{\circ}$ C. Lactobacillus plantarum is rod-shaped (0.5-1.5 to $1.0-10$ $\mu \mathrm{m})$ and is immobile (non-motile). L. plantarum is a facultative bacterium and can utilize oxygen as electron acceptor for cell growth and for product metabolism [15]. It is therefore desirable to comparatively evaluate lactic acid fermentation under aerobic and anaerobic conditions. Reference [16] have studied the fermentation of glucose under both aerobic and anaerobic conditions using L. plantarum. In the initial $®$ rst $4 \pm 5$ $\mathrm{h}$ of fermentation, the catabolite accumulating in the both media were similar.

Crude lactic acid, which may be upgraded by simple active carbon treatment and/or ion exchange to remove impurities and salts, can be directly used in a large number of food applications. Traditionally, taste, smell, and heat stability for color formation have been used to express lactic acid quality. The presence of acids (e.g., acetic acid and pyruvic acid), alcohols (e.g., methanol and ethanol), and esters can directly influence taste and smell [17]. 
TABLE III. SUMmary OF LACTIC ACID PURIFICATION METHOdS [2]

\begin{tabular}{|c|c|c|}
\hline $\begin{array}{c}\text { Lactic Acid } \\
\text { Purification } \\
\text { Method }\end{array}$ & Advantages & Disadvantages \\
\hline Crystallization & $\begin{array}{c}\text { Highly pure lactic acid } \\
\text { product }\end{array}$ & $\begin{array}{c}\text { Amount of mother } \\
\text { liquor by-product, } \\
\text { scalability }\end{array}$ \\
\hline $\begin{array}{c}\text { Esterification/distil } \\
\text { lation }\end{array}$ & $\begin{array}{c}\text { Highly pure acid, } \\
\text { scale-up }\end{array}$ & $\begin{array}{c}\text { Relatively high utility } \\
\text { cost, amount of } \\
\text { residue as by-product }\end{array}$ \\
\hline $\begin{array}{c}\text { Lactic acid } \\
\text { distillation }\end{array}$ & $\begin{array}{c}\text { Good splitting for } \\
\text { heavy } \\
\text { compounds }\end{array}$ & $\begin{array}{c}\text { Amount of residue as } \\
\text { by-product }\end{array}$ \\
\hline Extraction & Potentially high yield & $\begin{array}{c}\text { Complex (e.g., for } \\
\text { emulsion, entrainment }\end{array}$ \\
\hline
\end{tabular}

Table 3 show summary of lactic acid purification methods. Polymers may be either semi-crystalline or amorphous. Semicrystalline polymers have regular repeating units that allow the chains to fold into dense regions called crystallites. These act as crosslinks giving the polymer higher tensile strengths and higher modulus (stiffness) as compared to an amorphous analog. No polymer can completely organize into a fully crystalline material so there are still amorphous areas in semicrystalline polymers [18]. Characteristic temperatures of a polymer can be determined in several ways, but DSC (differential scanning calorimetry) is the most cited one. The flexibility of amorphous polymers is reduced drastically when they are cooled below a characteristic transition temperature called the Tg. At temperatures below $\mathrm{Tg}$, there is no segmental motion and any dimensional changes in the polymer are the result of temporary distortions of the primary valence bonds. Amorphous plastics, such as all the D,L-PLA containing ones perform best below $\mathrm{Tg}$, but elastomers must be used above the brittle point [19]. The Tg can be very important when studying mechanical properties (Table 4).

TABLE IV. PLA PROPERTIES [20]

\begin{tabular}{|c|c|}
\hline Crystalline structure & Semi-crystalline \\
\hline $\begin{array}{c}\text { Glass transition } \\
\text { temperature, } \mathbf{T g}\left({ }^{\circ} \mathbf{C}\right)\end{array}$ & $60-65$ \\
\hline $\begin{array}{c}\text { Melting temperature } \\
\text { (M) }\end{array}$ & $150-162$ \\
\hline Tensile modulus (GPa) & $2.7-16$ \\
\hline Tensile strength (MPa) & $21-60$ \\
\hline Elongation at break (\%) & $10-100$ \\
\hline Density (g/cm3) & $1.21-1.25$ \\
\hline
\end{tabular}

\section{CONCLUSION}

The potential of tofu dregs to provide the raw materials of PLA for sustainable packaging is enormous, based on the availability of abundant waste from the tofu-processing industry, as well as the content found in starch and other carbon sources, that serve as a fermentation substrate of lactic acid.

\section{ACKNOWLEDGMENT}

Authors would like to thank the Direktorat Pendidikan Tinggi Kemendikbud for providing the PKM-PE 2020 grant entitled "Poly Lactic Acid as Biodegradable Plastic Material Based on Tofu Dregs" and also to Mrs. Mustika Nuramalia Handayani, S.TP., M.Pd. as supervisor lecturer

\section{REFERENCES}

[1] R. Latief, "Teknologi Kemasan Plastik Biodegradable," Makalah Falsafah Sains (Pps 702) Program Pascasarjana/S3. Bogor: Institut Pertanian Bogor, 2001.

[2] W. Groot, J. Van Krieken, O. Sliekersl, and S. De Vos, "Production and purification of lactic acid and lactide," Poly (Lactic Acid) Synthesis, Structures, Properties, Processing, and Applications, pp. 1-18, 2010.

[3] En. Handarsari, and A. Syamsianah, "Analisis Kadar Zat Gizi, Uji Cemaran Logam Dan Organoleptik Pada Bakso Dengan Substituen Ampas Tahu," Prosiding Seminar Nasional \& Internasional UNIMUS, vol. 2, pp. $245-251,2010$.

[4] N. Amelia, A.G. Abdullah, and Y. Mulyadi, "Meta-Analysis Of Student Performance Assessment Using Fuzzy Logic,.” Indonesian Journal Of Science And Technology, vol. 4, pp. 74-88, 2019.

[5] H.D. Nugraha, R.V. Kencanasari, R.N. Komari, and K. Kasda, "Employability Skills In Technical Vocational Education And Training (TVET)," INVOTEC, vol. 16, pp. 1-10, 2020.

[6] J.F.M. De Almeida, A.G. De Oliveira, A.M.F. De Sousa, T.M.D. Fernandes, L.C. Bertolino, E.B.V. Pacheco, and A.L.N. Da Silva, "Toughness Improvement Of Poly (Lactic Acid) By The Addition Of Pre-Crosslinked Powdered Nitrile Rubber/Caco3 For Thermoforming Molding," Journal Of Elastomers \& Plastics, 0095244320958108, 2020.

[7] L. Avérous, Polylactic Acid: Synthesis, Properties And Applications, Dalam Monomers, Polymers And Composites From Renewable Resources (Ed Mohamed Naceur Belgacem Dan Alessandro Gandini), Chapter 21. 1st ed. Amsterdam : Elsevier Ltd. 2008.

[8] K.K. Bansal and J.M. Rosenholm, "Synthetic Polymers From Renewable Feedstocks: An Alternative To Fossil-Based Materials In Biomedical Applications," Therapeutic Delivery.

[9] H.A. Alhafiz, M.T. Isa, A.B. Sallau, and A.O. Ameh, "Delignification Of Corn Cob For The Synthesis Of Lactic Acid," Nsche Journal, vol. 35 , pp. 64-64, 2020

[10] M.A. Nastiti, "Pengaruh Konsentrasi Natrium Metabisulfit (Na2S2O5) dan Suhu Pengeringan Terhadap Karakteristik Tepung Ampas Tahu,' Jurnal Bioproses Komoditas Tropis, vol. 2, pp. 100-106, 2014.

[11] I. Hernaman, "Pengaruh Penggunaan Molases dalam Pembuatan Silase Campuran Ampas Tahu dan Pucuk Tebu Kering terhadap Nilai pH dan Komposisi Zat-Zat Makanannya (Effect of Using Molasses in Mix Silage Processing of Tofu Waste and Dry Top Cane on $\mathrm{pH}$ Value and Nutrient," Jurnal Ilmu Ternak Universitas Padjadjaran, vol. 5, 2005.

[12] S. Mulyani, and R.W. Wisma, "Analisis Proksimat Dan Sifat Organoleptik Oncom Merah Alternatif Dan Oncom Hitam Alternatif," JKPK (Jurnal Kimia dan Pendidikan Kimia), vol. 1, pp. 41-51, 2014. 
[13] H. Sudaryati, T. Mulyani, and E. Setiawan, "Kajian Substitusi Ampas Tahu Dan Penggunaan Natrium Bikarbonat Pada Pembuatan Tortilla", Jurnal Reka Pangan, Vol. 6, pp. 45 - 63, 2012.

[14] M. Hedberg, P. Hasslöf, I. Sjöström, S. Twetman, and C. StecksénBlicks. "Sugar Fermentation In Probiotic Bacteria - An In Vitro Study," Oral Microbiology Immunology, vol. 23, pp. 482-485, 2008.

[15] C.P. Tseng and T.J. Montville, "Enzymic regulation of glucose catabolism by Lactobacillus plantarum in an aerobic chemostat. Biotechnology progress," vol. 8, pp. 126-131, 1992.

[16] M.G. Murphy and S. Condon, "Comparison of aerobic and anaerobic growth of Lactobacillus plantarum in a glucose medium," Archives of microbiology," vol. 138, pp. 49-53, 1984.
[17] M.H. Hartmann, "High molecular weight polylactic acid polymers," In Biopolymers from renewable resources. Springer, Berlin, Heidelberg. 1998. pp. 367-411.

[18] J.C. Middleton and A.J. Tipton, "Synthetic biodegradable polymers as orthopedic devices," Biomaterials vol. 21, pp.2335-2346, 2000

[19] R.B. Seymour and C.E. Carraher, Polymer chemistry Vol. 181. New York: Marcel Dekker, 1981

[20] N. F. Zaaba and M. Jaafar, "A review on degradation mechanisms of polylactic acid: Hydrolytic, photodegradative, microbial, and enzymatic degradation,” Polymer Engineering and Science. pp. 2061- 2075, 2020 